\title{
IS VIOLA ULIGINOSA CRITICALLY ENDANGERED IN POLAND? - NEW DATA ON THE DISTRIBUTION OF THE SPECIES
}

\author{
RaFAŁ KrawCZYK ${ }^{1}$, AgNiESZKa Nobis $^{2 *}$, MARCin Nobis ${ }^{2}$, ANNA CWENER ${ }^{3}$ \\ ${ }^{1}$ Department of Nature Conservation, Maria Curie-Skłodowska University \\ Akademicka 19, 20-033 Lublin, Poland \\ e-mail: rkrawczy@biotop.umcs.lublin.pl \\ 2 Department of Plant Taxonomy and Phytogeography, \\ Institute of Botany, Jagiellonian University \\ Kopernika 27, 31-501 Kraków, Poland \\ * e-mail: agnieszka.nobis@uj.edu.pl \\ ${ }^{3}$ Department of Geobotany, Maria Curie-Skłodowska University \\ Akademicka 19, 20-033 Lublin, Poland
}

(Received: March 7, 2008. Accepted: July 10, 2008)

\begin{abstract}
Viola uliginosa Besser is a European species mainly known from the Baltic Region. It is endangered in a significant part of its range. Research carried out in the southeastern part of Poland led to the discovery of numerous sites of Viola uliginosa. Fourteen new localities of this species were found in the area of the Kotlina Sandomierska basin. This paper presents information concerning the localization of all new sites, the abundance of Viola uliginosa at the sites and habitats this species occupies. A discussion regarding the endangered status of this species in the Polish flora is given.
\end{abstract}

KEY WORDS: Viola uliginosa, distribution, population size, threatened species, Kotlina Sandomierska basin, Poland.

\section{INTRODUCTION}

Viola uliginosa Besser is a European species occurring mostly in the Baltic Region. It also occurs in Belarus, Ukraine and in the western part of Russia. The southernmost localities of this species are situated in Croatia (Valentine et al. 1968).

Viola uliginosa was originally described from Rząska near Cracow, Poland (locus classicus, Besser 1809). Afterwards, the occurrence of this species was reported from a few sites close to Rząska; however, according to Baryła and Kuta (2001), all of these in fact refer to the mentioned classical locality. The locus classicus of $V$. uliginosa is included in the Polish Nature Monitoring Programme. Furthermore, the population of $V$. uliginosa in Rząska has been molecularly studied by Cieślak et al. (2006).

Localities of Viola uliginosa are also known from different parts of Poland (Zając and Zając 2001). However, the occurrence of this species in the majority of these sites has not been confirmed (Baryła and Kuta 2001). The distribution of this species in different parts of Poland is still in need of study. In particular, it is vital to verify the data of previous florists, including herbarium material. For instan- ce, in the Opole Silesia Museum herbal specimens of $V$. uliginosa collected in the vicinities of Winów (leg. Bialucha, 06.05.1939, registration no. P/404) and Strzelce Opolskie (leg. Dziatzko 02.05.1897, registration no. P/1867) (Nowak and Nowak 2005) both seem be historical localities. An intentional survey for $V$. uliginosa carried out at these sites has brought negative results (A. Nowak, M. Kozak - pers. comm.).

After 1980, Viola uliginosa was reported in Poland from only five sites. According to Baryła and Kuta (2001), localities of Viola uliginosa (in Poland) are to be found in Rząsiecki Forest (near Cracow), Majdan Królewski, Huta Komorowska and Łysaków (near Zaklików). In 2003 a fifth site of the species was documented in Kamionka village, situated to the west of Majdan Królewski (Cieślak et al. 2004).

Field studies carried out in the Kotlina Sandomierska basin revealed new data on the occurrence of this species in southeastern Poland, at the southern continuous range limit of this species. The discovery of more than a dozen new localities of Viola uliginosa has broadened our knowledge regarding its habitat requirements and induced us to verify opinions on the conservation status of this plant in Poland. 


\section{METHODS}

Field investigations were carried out between 2002-2007 in the flowering period of Viola uliginosa i.e., from midApril to June. The entire area of the Kotlina Sandomierska basin was surveyed. All potential sites of occurrence of $V$. uliginosa were inventoried for the presence of this species. All localities of $V$. uliginosa were assigned to the proper cartogram unit of the ATPOL grid. The digits which follow letter symbols of a large square (with a side of $100 \mathrm{~km}$ ) indicate the following: the first two - the number of the cartogram unit with a side of $10 \mathrm{~km}$; the following two indicate the cartogram unit number with a side of $2 \mathrm{~km}$ (Zając 1978). In the list of localities presented below, the position of these localities relative to the closest towns or villages are also given. The approximate abundance of individuals within populations and short general descriptions of the habitats are presented.

\section{RESULTS}

\section{A LIST OF NEW LOCALITIES OF VIOLA ULIGINOSA}

\section{Dąbrowa Rzeczycka}

Location: The site encompasses an area of several square kilometres between three villages: Dąbrowa Rzeczycka, Lipa and Goliszowiec (north of Stalowa Wola).

Abundance: more than 1 million leaf rosettes with generative shoots.

Habitat: Viola uliginosa mainly occurs in an area along two forest watercourses (one of which has a periodic character, it flows exclusively during the spring and in the beginning of the summer). The species can also be found by water drainage ditches. Much of the area is wet and flooded in spring. Beaver activity has a great impact on the habitats. V. uliginosa was also noted in alder forests, wet mixed forests, forest glades, abandoned meadows (overgrown in various stages of succession) and also in a wet scrub (consisting of Frangula alnus and Salix cinerea). ATPOL: FE 9422, FE 9423, FE 9424.

\section{Lipa}

Location: ca. $4 \mathrm{~km}$ to the west of Lipa village and ca. $4 \mathrm{~km}$ to the north of Wola Rzeczycka (north of Stalowa Wola). Abundance: ca. 10 thousand leaf rosettes with generative shoots.

Habitat: The population of Viola uliginosa was observed along a small, periodically drying forest watercourse called Jodłówka. It is most abundant in sites slightly distant from the watercourse, characterised by difficult drainage of standing water in spring. The species grows in riparian forest and marshy meadows.

ATPOL: FE 9401.

\section{Gielnia}

Location: ca. $2 \mathrm{~km}$ to the northeast of Gielnia village near Lipa (north of Stalowa Wola).

Abundance: ca. 5 thousand leaf rosettes with generative shoots.

Habitat: The locality is situated near a small forest watercourse named Złodziejka. Viola uliginosa grows in a marshy scrub that constitutes the regenerative stage of alder forest. ATPOL: FE 8540, FE 8541.

\section{Pikule}

Location: near the road linking Janów Lubelski and Łążek, ca. $3 \mathrm{~km}$ to the southwest of Janów Lubelski.

Abundance: ca. 300 leaf rosettes with generative shoots. Habitat: Viola uliginosa was noted in riparian forest and a wet meadow in the valley of a small river called Trzebensz.

ATPOL: FE 9612.

\section{Janów Lubelski}

Location: near the road linking Janów Lubelski and Szklarnia village (by the hamlet of Cegielnia).

Abundance: ca. 1000 leaf rosettes with generative shoots. Habitat: Viola uliginosa occurs in the Trzebensz river valley. The species was noted in meadow and rush communities, peat-bogs and wet scrub. A small number of individuals was also observed in alder riparian forest located along the first forest watercourse by the road linking Janów Lubelski and Flisy.

ATPOL: FE 9700, FE 9701.

\section{Szklarnia}

Location: Szklarnia reserve, ca. $1 \mathrm{~km}$ to the east of the town of Szklarnia (near Janów Lubelski).

Abundance: ca. 100 leaf rosettes with generative shoots. Habitat: Viola uliginosa was noted in alder riparian forest in the vicinity of a small watercourse called Czartosowa. ATPOL: FE 9720, FE 9721.

\section{Huta Krzeszowska}

Location: ca. $1 \mathrm{~km}$ to the east of Huta Krzeszowska (to the east of Nisko).

Abundance of population: ca. 500 leaf rosettes with generative shoots.

Habitat: The species was noted in alder riparian forest. ATPOL: FF 0744.

\section{Glinianka}

Location: ca. $1.5 \mathrm{~km}$ to the northeast of Glinianka village (southeast of Stalowa Wola).

Abundance: 20-30 thousand leaf rosettes with generative shoots.

Habitat: Viola uliginosa occurs along a forest watercourse (in some places strongly regulated) and its tributaries. The species was noted in alder forest and rush communities. ATPOL: FF 1612, FF 1613, FF 1623.

\section{Przymiarki}

Location: the eastern end of a forest complex called Wielki Bór, to the northwest of the settlement of Przymiarki (near Sieniawa).

Abundance: ca. 10 thousand leaf rosettes with generative shoots.

Habitat: Viola uliginosa is most abundant in a small, partially retained alder forest characterised by disturbed undergrowth (in some places dominated by Solidago gigantea). The species was also noted in the contact zone of the TilioCarpinetum association and Magnocaricion communities. ATPOL: FF 4803.

\section{Dobcza}

Location: ca. $1.5 \mathrm{~km}$ to the east of Misany settlement, near Dobcza village (close to Sieniawa). 


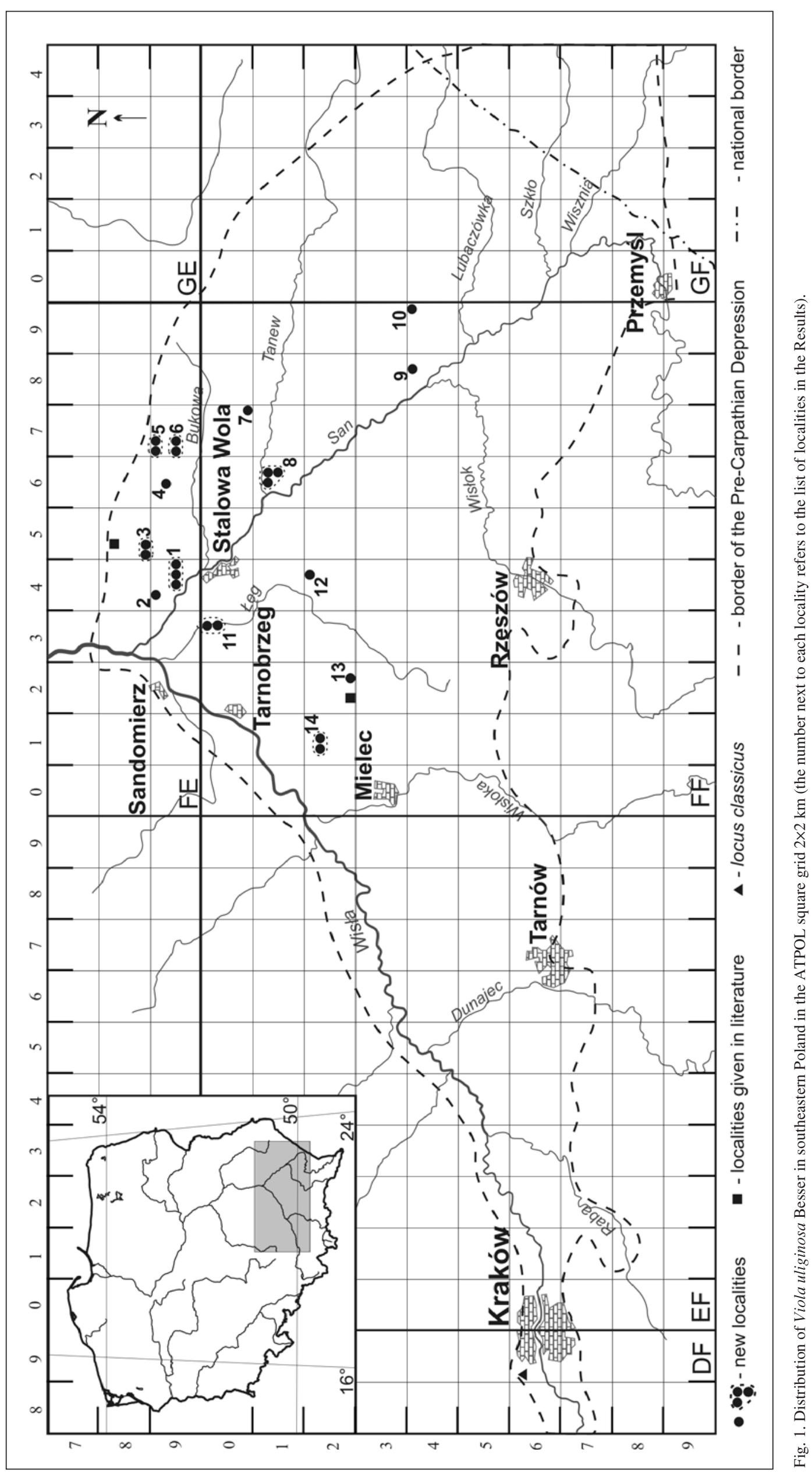


Abundance: ca. 500 leaf rosettes with generative shoots. Habitat: Viola uliginosa occurs in a narrow, developed strip of alder forest along a watercourse with stagnating waters in the springtime.

ATPOL: FF 4904.

\section{Kotowa Wola}

Location: ca. $1 \mathrm{~km}$ to the south of the town of Kotowa Wola, near Grębów (northwest of Stalowa Wola).

Abundance: ca. 2 thousand leaf rosettes with generative shoots.

Habitat: Viola uliginosa was discovered in a wide, drained depression which is mainly occupied by rush communities and scrub (consisting of Alnus glutinosa and Padus avium), in some places with a major participation of Solidago gigantea. ATPOL: FF 0303, FF 0313.

\section{Zalesie near Jeżowe}

Location: ca. $2 \mathrm{~km}$ to the north of the western part of Zalesie village near Jeżowe (the vicinity of Nisko).

Abundance: ca. 200 leaf rosettes with generative shoots.

Habitat: Viola uliginosa occurs in drainage ditches located on both sides of the forest track. It is situated near an artificial stand of pine with a few spruce and also, rarely, along a watercourse in partially retained belts of alder forest. ATPOL: FF 2403.

\section{Komorów}

Location: ca. $1 \mathrm{~km}$ to the east of Komorów village (southeast of Baranów Sandomierski).

Abundance: ca. 100 leaf rosettes with generative shoots.

Habitat: This population of Viola uliginosa occupied dried alder forest.

ATPOL grid: FF 2243.

\section{Durdy}

Location: ca. $1 \mathrm{~km}$ to the south and southwest of Durdy village (near Baranów Sandomierski).

Abundance: ca. 100 leaf rosettes with generative shoots.

Habitat: Viola uliginosa was observed along a watercourse flowing by the edge of a forest complex. The species is a component of a narrow belt of alder forest. It also occurs on the borders of a wet meadow.

ATPOL: FF 2111, FF 2112.

\section{CONCLUSIONS}

At the beginning of this field study, Viola uliginosa was considered as one of the rarest elements of Polish flora. The species was included in the Polish Plant Red Data Book (Baryła and Kuta 2001) and on the 'red list' of vascular plants endangered in Poland (Zarzycki and Szeląg 2006). Baryła and Kuta (2001) recognised this species as critically endangered in Poland. Moreover, the species is endangered across most of its range, as demonstrated by its inclusion in the 'red list' of the Baltic Region (Ingelög et al. 1993). In particular countries the status of $V$. uliginosa varies. For instance in Denmark (Stoltze and Pihl 1998) and in the northern part of the Leningrad Region (Kotiranta et al. 1998) it is categorised as a rare species (R). In Sweden (Gärdenfors 2005) and Finland (Ryttäri and Kettunen 1997) V. uliginosa is considered vulnerable (category VU). In Belarus it is classified as a near threatened species (category NT) (2005), whereas in Germany it is regarded as threatened with extinction (Korneck et al. 1996). In Croatia, where the range of the species reaches its southwestern limit, the status of Viola uliginosa is unknown (category DD) (Zgaga 2006).

According to the IUCN principles, a species may be considered as critically endangered only if it fulfils one of several criteria (IUCN 2001). The most important of these are a significant decline in population number (which has been observed in the past 10 years or is predicted to happen in the next 10 years), a small total range or a small absolute area of occurrence.

In the light of the presented data, the degree of threat of Viola uliginosa in Poland is undoubtedly lower than proposed by Baryła and Kuta (2001). This is indicated by the 14 new locations of $V$. uliginosa found during only 6 years of study (Fig. 1). In the newly encountered localities the number of individuals within particular populations amounts from 100 to over 1 million (!) flowering specimens. The significant size of populations is also characteristic for the locality discovered in the Kotlina Sandomierska basin by Cieślak and co-authors (2004). As our observations suggest, $V$. uliginosa possesses a quite broad habitat spectrum and is rather resistant to terrain drainage. It blooms not only in wet areas but also in drier ones in which adjustments of watercourses were carried out several years ago. Thus, there is no reason to anticipate a significant decline in the number of $V$. uliginosa populations in the investigated area. Nonetheless, a change in the ground water level still remains the main threat to this species in Poland as a whole. This is associated with (among others) the expansion of invasive plants (e.g. Solidago gigantea) that change the structure of communities in $V$. uliginosa habitats.

All extant sites are located in the Kotlina Sandomierska basin which constitutes a significant part of the Pre-Carpathian Depression. In comparison with the surrounding areas this region is distinctive for its specific geological and hydrological conditions. The basin is filled with impervious Miocenic clays covered by sandy deposits (Buraczyński and Wojtanowicz 1969; Kondracki 2002). This layout of shallow, buried clays provides stable and sufficient substrate humidity and therefore has a vital influence on habitat formation.

The relatively large number of discovered locations is definitely not the result of a recent expansion of Viola uliginosa. The species does not possess any effective diaspore dispersal mechanisms which would enable rapid migration and gaining of new terrain. Ants participate in $V$. uliginosa seed scattering (myrmecochory). The lack of data on V.uliginosa distribution in the Kotlina Sandomierska basin has been the effect of an insufficient number of botanical surveys over most of this area. On the other hand, the short flowering period of $V$. uliginosa, which is difficult to identify in a vegetative state, may also be of significance. Moreover, during summer the undergrowth in which this species occurs is dominated by much taller plants. Leaf rosettes are thus hardly noticeable or are difficult to distinguish from vegetative specimens of other Viola species.

The data collected during field investigations on the distribution and abundance of Viola uliginosa populations explicitly indicates that the present status of this species needs to be modified. As argued by Zarzycki and Szeląg 
(2006), it should probably be included into the group of vulnerable species - category VU. However, in order to unambiguously establish the status of $V$. uliginosa in Poland, data on its occurrence over a larger area should be verified. Only intentional field investigations carried out in sites known from the literature and re-examination of herbal material can verify if reports on the occurrence of $V$. uliginosa near Kalisz, Warszawa, Białowieża or in the $\mathrm{Ku}$ jawy region (Zając and Zając 2001) are indeed wrong or if the plant became extinct at these sites, as probably happened in Opole province.

\section{ACKNOWLEDGEMENTS}

The authors thank Prof. Adam Zając and an anonymous reviewer for helpful comments improving the manuscript.

\section{LITERATURE CITED}

BESSER W.S. 1809. Primitiae Florae Galiciae Austriacae utriusque. I. Sumptibus Ant. Doll., Vienna, pp. xviii + 399 .

BURACZYŃSKI J., WOJTANOWICZ J. 1969. Zagadnienia geomorfologiczne północnej części Kotliny Sandomierskiej w widłach Wisły i Sanu. Folia Soc. Sci. Lub., Sect. D, 7/8: 3-44. (in Polish)

BARYŁA J., KUTA E. 2001. Viola uliginosa Besser. Fiołek bagienny. In: R. Kaźmierczakowa, K. Zarzycki (eds), Polska czerwona księga roślin. Paprotniki i rośliny kwiatowe. Instytut Botaniki im. W. Szafera, Instytut Ochrony Przyrody, Polska Akademia Nauk, Kraków, pp. 245-247. (in Polish with English summary)

CIEŚLAK E., PAUL W., CIEŚLAK J. 2004. Bogate stanowisko Viola uliginosa Bess. (Violaceae) w Kotlinie Sandomierskiej. Fragm. Flor. Geobot. Polon. 11 (1): 206-209. (in Polish with English summary)

CIEŚLAK E., PAUL W., RONIKIER M. 2006. Low genetic diversity in the endangered population of Viola uliginosa in its locus classicus at Rząska near Cracow (Southern Poland) as revealed by AFLP markers. Acta Soc. Bot. Pol. 75(3): 245$-251$.

GÄRDENFORS U. (ed.) 2005. Rödlistade arter i Sverige 2005. The 2005 Red List of Swedish Species. ArtDatabanken, SLU, Uppsala, pp. 179. (in Swedish)
HORUZIK L.I. [ХОРҮЖИК Л.И.] (ed.). 2005. Красная книга Республики Беларусь: Реdкие и находящиеся под угрозой исчеэновения виды дикораснущих растний. [Red Data Book of the Republic of Belarus: Rare and threatened plant of native species]. Minsk, pp. 84-86. (in Russian)

INGELÖG T., ANDERSSON R., TJERNBERG M. (eds). 1993. Red data book of the Baltic Region. Part 1. List of threatened vascular plants and vertebrates. Swedish Threatened Species Unit, Upsala \& Institute of Biology, Riga, pp. 25-68.

IUCN Red List Categories and Criteria Ver. 3.1. 2001. IUCN The World Conservation Union.

KORNECK D., SCHNITTLER M., VOLLMER I. 1996. Rote Liste der Farn- und Blütenpflanzen (Pteridophyta et Spermatophyta) Deutschlands. In: Rote liste gefährdeter Pflanzen Deutschlands. Schriftenreihe für Vegetationskunde 28: 21-187.

KOTIRANTA H., UOTILA P., SULKAVA S., PELTONEN S. (eds). 1998. Red Data Book of East Fennoscandia. Ministry of the Environment, Helsinki, pp. 31- 47.

NOWAK A., NOWAK S. 2005. Katalog zielnika roślin naczyniowych Muzeum Śląska Opolskiego. Zbiory z lat 1829-1943 z terenów dzisiejszej Polski. Muzeum Śląska Opolskiego w Opolu, Opole, pp. 145. (in Polish with English and German summary)

RYTTÄRI T., KETTUNEN T. (eds). 1997. Uhanalaiset kasvimme. [Threatened plants in Finland]. Kirjayhtymä, Helsinki, pp. 335. (in Finnish)

STOLTZE M., PIHL S. (ed.) 1998: Rødliste 1997 over planter og dyr i Danmark. [The Danish 1997 Red List]. Miljø- og Energiministeriet, Danmarks Miljøunderšrgelser og Skov- og Naturstyrelsen, pp. 71-81. (in Danish with English summary)

VALENTINE D.H., MERXMÜLLER H., SCHMIDT A. 1968. Viola L. In: Tutin T.G., Heywood V.H., Burges N.A., Moore D.M., Valentine D.H., Walters S.M., Webb D.A. (eds), Flora Europaea. Vol. 2. Cambridge University Press, Cambridge.

ZAJĄC A. 1978. Atlas of distribution of vascular plants in Poland (ATPOL). Taxon 27 (5/6): 481-484.

ZAJĄC A., ZAJĄC M. (eds) 2001. Atlas rozmieszczenia roślin naczyniowych w Polsce. Nakładem Pracowni Chorologii Komputerowej Instytutu Botaniki Uniwersytetu Jagiellońskiego, Kraków, pp. xii +716 .

ZARZYCKI K., SZELĄG Z. 2006. Red list of the vascular plants in Poland. In: Z. Mirek, K. Zarzycki, W. Wojewoda, Z. Szeląg (eds), Red list of plants and fungi in Poland. Instytut Botaniki im. W. Szafera Polska Akademia Nauk, Kraków, pp. 11-20.

ZGAGA Ž. 2006. Biodiversity assessment update for Croatia. August 2005. August 2005. http://croatia.usaid.gov/pdf-stories/biodiversity-report.pdf 